\title{
Synthesis of tert-butyl 5-amino-4 - ((2- (dimethylamino) ethyl) (methyl) amino) -2- methoxyphenyl) Carbamate
}

\author{
Bingbing Zhao ${ }^{1}$, Yuping Guo ${ }^{1}$, Zhou Lan ${ }^{1}$ and Shan $\mathrm{Xu}^{1, \mathrm{a}^{*}}$
}

${ }^{1}$ School of Pharmacy, Jiangxi Science \& Technology Normal University, Nanchang 330013, China

*ashanxu9891@126.com

*The corresponding author

Keywords: 4-Fluoro-2-methoxy-5-nitroaniline; Tert-Butyl 5-amino-4 - ((2-(dimethyl- amino) ethyl) (methyl) amino) -2- methoxyphenyl) carbamate; Synthesis

\begin{abstract}
Tert-Butyl 5-amino-4 - ((2-(dimethyl- amino) ethyl) (methyl) amino) -2- methoxyphenyl) carbamate (1) is an important intermediate in many biologically active compounds such as omisertinib (AZD9291). In this work, a rapid synthetic method for compound 1 was established. The compound 1 was synthesized from the commercially available 4-fluoro-2- methoxy-5nitroaniline through three steps including acylation, nucleophilic substitution and reduction. The structures were confirmed by MS and 1HNMR. Furthermore, the synthetic method was optimized, and the total yield of the three steps was $81 \%$.
\end{abstract}

\section{Introduction}

AZD9291 is a novel oral, potent and selective third-generation irreversible inhibitor of both EGFR-sensitising and T790M resistance mutants ${ }^{[1-4]}$. It has a good therapeutic effect on non-small cell lung cancer (NSCLC) tumors, compared with the first-generation gefitinib and the second-generation erlotinib ${ }^{[5-11]}$. There are two synthetic methods documented for the synthesis of AZD9291 ${ }^{[12]}$. They both have high reaction temperature, time consuming, low yield, harmful to environment and other shortcomings. However, the synthesis of AZD9291 with tert-butyl 5-amino-4 - ((2-(dimethyl- amino) ethyl) (methyl) amino) -2- methoxyphenyl) carbamate as the key intermediate has less reported ${ }^{[13]}$. In this study, we optimized the synthesis of compound 1, taking 4-fluoro-2methoxy- -5 -nitroaniline ${ }^{[14]}$ as a starting material. The final product compound 1 was obtained by acylation, nucleophilic substitution and reduction.<smiles>C=CC(=O)Nc1cc(Nc2nccc(-c3cn(C)c4ccccc34)n2)c(OC)cc1N(C)CCN(C)C</smiles>

Fig. 1 Sructures of AZD9291<smiles>COc1cc(N(C)CCN(C)C)c(N)cc1NC(=O)O</smiles>

Fig. 2 Compound 1

In this study, we designed and optimized the synthetic methods for tert-butyl 5-amino-4 - ((2(dimethylamino) ethyl) (methyl) amino) -2- methoxyphenyl) carbamate and make it more suitable for industrial production. The structures of AZD9291 and compound 1 were shown in Fig 1 and Fig 2 , respectively. 


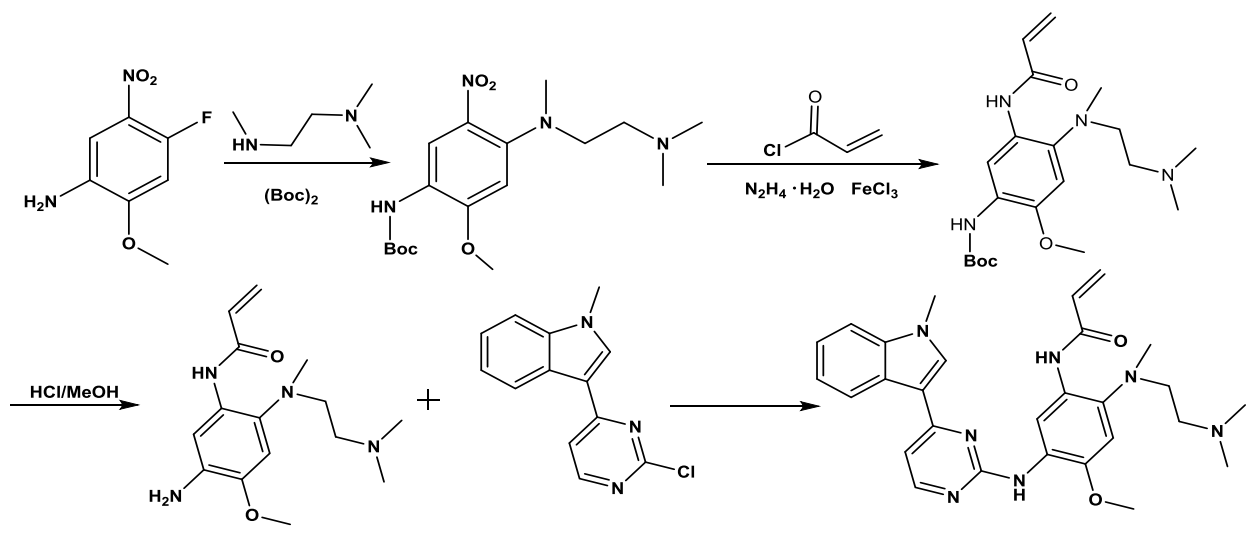

Scheme 1. The synthetic route of AZD9291

\section{Materials and Methods}

NMR spectra were performed using Bruker $300 \mathrm{MHz}$ spectrometers (Bruker Bioscience, Billerica, MA, USA) with TMS as an internal standard. Mass spectra (MS) were taken in ESI mode on Agilent 1100 LC-MS (Agilent, Palo Alto, CA, USA). Elemental analysis was determined on a Carlo-Erba 1106. Elemental analysis instrument (Carlo Erba, Milan, Italy). All the materials were obtained from commercial suppliers and used without purification, unless otherwise specified. Yields were not optimized. TLC analysis was carried out on silica gel plates GF254 (Qindao Haiyang Chemical, China).

\section{Synthesis of Compounds}

The structures and the synthetic route were shown in Scheme 2<smiles>COc1cc(F)c([N+](=O)[O-])cc1N</smiles>

2<smiles>CNCCN(C)C</smiles>

3<smiles>COc1cc(N(C)CCN(C)C)c([N+](=O)[O-])cc1NC(=O)OCCN(C)c1cc(OC)c(N(C)CCN(C)C)cc1N</smiles>

4

1

Scheme 2. The synthetic route of compound 1

Reagents and conditions: (a) $\mathrm{Boc}_{2} \mathrm{O}$, triethylamine, DMAP (4-dimethylaminopyridine), $40{ }^{\circ} \mathrm{C}$. (b) $\mathrm{N}_{1}, \mathrm{~N}_{1}, \mathrm{~N}_{2}$-trimethylethane-1,2-diamine, DIPEA (N,N-Diisopropylethylamine), $140{ }^{\circ} \mathrm{C}$. (c) $80 \%$ hydrazine hydrate, $\mathrm{FeCl}_{3}$, activated carbon, $60{ }^{\circ} \mathrm{C}-80{ }^{\circ} \mathrm{C}$.

(4-Fluoro-2-methoxy-5-nitro-phenyl)-carbamic acid tert--butyl ester (3)

A solution of 4-fluoro-2-methoxy-5-nitroaniline $(4.0 \mathrm{~g}, 21.5 \mathrm{mmol})$, triethylamine $(32.25 \mathrm{mmol})$ and DMAP $(0.52 \mathrm{~g}, 4.3 \mathrm{mmol})$ in DCM (dichloromethane) $(50 \mathrm{~mL})$ was cooled to $0-5{ }^{\circ} \mathrm{C}$ in an ice/water bath. $\mathrm{Boc}_{2} \mathrm{O}(9.4 \mathrm{~g}, 43.0 \mathrm{mmol})$ in DCM $(30 \mathrm{~mL})$ was added to the mixture slowly. The progress of the reaction was monitored by TLC. After completion of the reaction, extracted with DCM (300 mL*3), and the organic layer was separated, dried over anhydrous sodium sulfate, and concentrated under reduced pressure to yield product $(5.5 \mathrm{~g}, 90 \%)$ as a yellow solid. ${ }^{1} \mathrm{H}$ NMR (400 $\mathrm{MHz}, \mathrm{DMSO}) \delta=8.57(\mathrm{~s}, 1 \mathrm{H}), 8.53(\mathrm{~s}, 1 \mathrm{H}), 7.28(\mathrm{~s}, 1 \mathrm{H}), 3.94(\mathrm{~s}, 3 \mathrm{H}), 1.47(\mathrm{~s}, 9 \mathrm{H}) . \mathrm{MS}(\mathrm{ESI}): \mathrm{m} / \mathrm{z}$ $286.1[\mathrm{M}+\mathrm{H}]^{+}$. 
\{4-[(2-Dimethylamino-ethyl)-methyl-amino]-2-methoxy-5-nitrophenyl\}-carbamic acid tertbutyl ester (4)

$\mathrm{N}_{1}, \mathrm{~N}_{1}, \mathrm{~N}_{2}$-Trimethylethane-1,2-diamine $(2.7 \mathrm{~g}, 27.0 \mathrm{mmol})$ was added to a solution of (4-fluoro-2-methoxy-5-nitro-phenyl)-carbamic acid tert-butyl ester (6.3g, $22.0 \mathrm{mmol}$ ) and DIPEA (N,N-Diisopropylethylamine) $(3.82 \mathrm{~mL}, 22.0 \mathrm{mmol})$ in DMA (N,N-Dimethylacetamide) (100 mL). The mixture was heated to $60{ }^{\circ} \mathrm{C}$ and stirred at this temperature for $2 \mathrm{~h}$. Water $(200 \mathrm{~mL})$ was added to the reaction mixture, which was then extracted with DCM $\left(50 \mathrm{~mL}^{*} 3\right)$. The combined extracts were dried over anhydrous sodium sulfate. The solvent was removed under vacuum to give product as an orange solid (7.5 g, 92\%), ${ }^{1} \mathrm{H}$ NMR (400 MHz, DMSO) $\delta=8.34(\mathrm{~s}, 1 \mathrm{H}), 8.23(\mathrm{~s}, 1 \mathrm{H}), 6.87$ (s, $1 \mathrm{H}), 3.94(\mathrm{~s}, 3 \mathrm{H}), 3.50(\mathrm{t}, \mathrm{J}=6.8,2 \mathrm{H}), 3.27(\mathrm{t}, \mathrm{J}=6.7,2 \mathrm{H}), 2.78(\mathrm{~d}, \mathrm{~J}=8.3,9 \mathrm{H}), 1.45$ (s, 9H). MS (ESI): $\mathrm{m} / \mathrm{z} 368.2[\mathrm{M}+\mathrm{H}]^{+}$.

\section{tert-butyl 5-amino-4 - ((2- (dimethylamino) ethyl) (methyl) amino) -2- methoxyphenyl) carbamate (1)}

A solution of \{4-[(2-Dimethylamino-ethyl)-methyl-amino]-2-methoxy-5- nitrophenyl $\}$-carbamic acid tert-butyl ester $(2.5 \mathrm{~g}, 6.8 \mathrm{mmol})$ in ethanol, after heated to $60{ }^{\circ} \mathrm{C}, \mathrm{FeCl}_{3}(0.5 \mathrm{~g}, 3.0 \mathrm{mmol})$ and activated carbon was added in such degree. Continue to heat to $80{ }^{\circ} \mathrm{C}, 80 \%$ hydrazine hydrate $(1.7$ $\mathrm{g}, 34.0 \mathrm{mmol}$ ) was added to the reaction mixture. The resulting mixture was stirred at $80{ }^{\circ} \mathrm{C}$ for $1 \mathrm{~h}$, and then cooled to r.t. The resulting filtrate was collected by filtration, washed with ethanol, the filtrate extracted with DCM (300 $\left.\mathrm{mL}^{*} 3\right)$, and the organic layer was separated, dried over anhydrous sodium sulfate, and concentrated under reduced pressure to give yellow oily liquid $(2.5 \mathrm{~g}, 98 \%)$. ${ }^{1} \mathrm{H}$ NMR (400 MHz, DMSO) $\delta=8.21(\mathrm{~s}, 1 \mathrm{H}), 7.48(\mathrm{~s}, 1 \mathrm{H}), 7.03(\mathrm{~s}, 1 \mathrm{H}), 6.60(\mathrm{~s}, 2 \mathrm{H}), 3.91(\mathrm{~s}, 3 \mathrm{H})$, $3.47(\mathrm{t}, \mathrm{J}=6.8,2 \mathrm{H}), 3.24(\mathrm{t}, \mathrm{J}=6.7,2 \mathrm{H}), 2.75(\mathrm{~d}, \mathrm{~J}=8.3,9 \mathrm{H}), 1.42(\mathrm{~s}, 9 \mathrm{H}) . \quad \mathrm{MS}(\mathrm{ESI}): \mathrm{m} / \mathrm{z}$ $338.2[\mathrm{M}+\mathrm{H}]^{+}$.

\section{Conclusions}

In conclusion, tert-butyl 5-amino-4 - ((2- (dimethylamino) ethyl) (methyl) amino) -2methoxyphenyl) carbamate was synthesized from the commercially available 4- fluoro-2methoxy-5-nitroaniline through three steps including acylation, nucleophilic substitution and reduction. The synthetic method of compound 1 and the reactions conditions were optimized, the purity of the product was much higher. Its structure was confirmed by MS and ${ }^{1} \mathrm{H}$ NMR spectrum.

\section{Acknowledgments}

We gratefully acknowledge the generous support provided by Natural Science Foundation of Jiangxi Science \&Technology Normal University (2016XJZD007) and Program of Key Laboratory of Drug Design and Optimization, Jiangxi Science \& Technology Normal University (300098010306) and College Students' Science and Technology Innovation Project of Jiangxi Province.

\section{Reference}

[1] Eberlein C, Stetson D, Markovets A, et al. Acquired resistance to the mutant-selective EGFR inhibitor AZD9291 is associated with increased dependence on RAS signaling in preclinical models [J]. Cancer Research, 2015, 75(12): 2489-2500.

[2] Cross D, Ashton S, Nebhan C, et al. Abstract A109: AZD9291: an irreversible, potent and selective third generation tyrosine kinase inhibitor (TKI) targeting EGFR activating (EGFRm+) and resistance (T790M) mutations in advanced lung adenocarcinoma [J]. Molecular Cancer Therapeutics, 2014, 12(11):A109-A109. 
[3] Cross D, Ashton S, Ghiorghiu S, et al. AZD9291, an irreversible EGFR TKI, overcomes T790M-mediated resistance to EGFR inhibitors in lung cancer [J]. Cancer Discovery, 2014, 4(9): 1046-1061.

[4] Thress K, Paweletz C, Felip E, et al. Acquired EGFR C797S mediates resistance to AZD9291 in advanced non-small cell lung cancer harboring EGFR T790M[J]. Nature Medicine, 2015, 21(6): $560-562$.

[5] Jiang T, Zhou C. Clinical activity of the mutant-selective EGFR inhibitor AZD9291 in patients with EGFR inhibitor-resistant non-small cell lung cancer [J]. Translational Lung Cancer Research, 2014, 3(6): 370-372.

[6] Ricciuti B, Chiari R, Chiarini P, et al. Osimertinib (AZD9291) and CNS response in two radiotherapy-naïve patients with EGFR -mutant and T790M-positive advanced Non-Small Cell Lung Cancer [J]. Clinical Drug Investigation, 2016, 36(8): 683-686.

[7] Passaro A, Alesini D, Pochesci A, et al. Erlotinib and gefitinib for elderly patients with advanced non-small-cell lung cancer [J]. Anti-cancer agents in medicinal chemistry, 2014, 14(5): 646-650.

[8] Nguyen K, Kobayashi S, Costa D. Acquired resistance to epidermal growth factor receptor tyrosine kinase inhibitors in Non-Small-Cell Lung cancers dependent on the epidermal growth factor receptor pathway [J]. Clinical Lung Cancer, 2009, 10(4): 281-289.

[9] Watanabe S, Minegishi Y, Yoshizawa H, et al. Effectiveness of gefitinib against non-small-cell lung cancer with the uncommon EGFR mutations G719X and L861Q[J]. Journal of Thoracic Oncology Official Publication of the International Association for the Study of Lung Cancer, 2014, 9(2): 189-194.

[10] Pasi A , James Y, Dong W, et al. AZD9291 in EGFR inhibitor-resistant non-small-cell lung cancer [J]. New England Journal of Medicine, 2015, 372(18): 1689-1699.

[11] Jiang T, Zhou C. Clinical activity of the mutant-selective EGFR inhibitor AZD9291 in patients with EGFR inhibitor-resistant non-small cell lung cancer [J]. Translational Lung Cancer Research, 2014, 3(6): 370-372.

[12] Finlay M, Anderton M, Ashton S, et al. Discovery of a potent and selective EGFR inhibitor (AZD9291) of both sensitizing and T790M resistance mutations that spares the wild type form of the receptor [J]. Journal of Medicinal Chemistry, 2014, 57(20): 8249-8267.

[13] Gu B, Ji W, Huang X, et al. Concentration-dependent two-photon absorption and subsequent excited-state absorption in 4-methoxy-2-nitroaniline [J]. Journal of Applied Physics, 2009, 106(3): 033511-033511-4.

[14] Ward R, Anderton M, and Ashton S, et al. Structure- and reactivity-based development of covalent inhibitors of the activating and gatekeeper mutant forms of the epidermal growth factor receptor (EGFR) [J]. Journal of Medicinal Chemistry, 2013, 56(17): 7025-7248. 